\title{
POLLEN SURVEY AND ITS CLINICAL SIGNIFICANCE
}

\author{
By \\ SHINSAK HORIGUTI, M. D., and Yozo SAITO, M. D. \\ From the Department of Oto-Rhino-Laryngology, School of Medicine, \\ Tokyo Medical and Dental University. (Tokyo)
}

In 1963, the authors reported the cases of Japanese cedar pollinosis in Nikko, Japan. This necesitated a pollen survey in making diagnosis of pollinosis.

Therefore the pollen counts were carried out in Tokyo during 1964 and in Nikko from March to May in 1963 and 1964. Vaseline-coated slides were exposed to air for 24 hours. The results obtained were illustrated in the figures.

Three pollinating seasons were observed in Tokyo. Tree season was recognised in February-May, grass season in May-November, and ragweed season in August-Septeber. Predominant pollens were Cryptomeria japonica (Japanese cedar), Chamaecyparis obtusa, Pinaceae, Ambrosia elatior and Digitaria adscendens.

In Nikko, tree season was recognised in MarchMay and predominant pollens were Cryptomeria japonica, Betulaceae and Pinus densiflora. The highest peak of Japanese cedar pollen count was observed in eary April with a maximum count of 70 grains in Nikko.

Effects of humidity on dispersal of Japanese cedar pollen were observed. It was shown that there was a correlation between humidity and dispersal of pollens.

Some clinical observations on antigenicity of pollens were carried out.

Pollen counts as a factor in the development of Japanese cedar pollinosis was studied.

Some reasons for absence of pollinosis in Japan were discussed. A reason might be attributed to the lack of investigations on pollinosis in Japan.

The authors emphasized the importance and necessity of pollen survey in Japan.

\section{空中飛散花粉の検索とその臨床的意義}

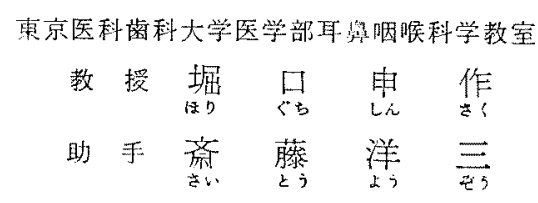

\section{縉 言}

花㸮措 (Pollinosis) は植物の花粉 (Pollen) によつ て茞起きれるものであり，フレルギー性疾患の代表的な もので吉る。位つてその研究は，臨床アレルギーの進步 発展と密接不可分の関係にあるものと考劣られる。

花粉㱏の発生には，原因となる花粉が空中に存在する こしが第1条件である。しかしながら花粉が存在しても
必ずし子花粉症が発生するとは限らず，花粉の抗原性し 量とが問題になる．抗原性は花粉の種類によつてる異な り，非常に强いものから㱠ど抗原性のないむのまであ る。量は一般にはある程度以上多いことが必要とされて いる．往つて風煤花の花粉が重要な役割を演ずる訳であ る.更に風媒花であれば，その飛散量は気象条件に左右 されることが充分考えられる。 
著者らは1963 年栃木県日光地方にみられたアレルギ 一性番炎患者のフレルゲン检索を目的とし，空中飛散花 沼ならびに開花暦の検索をも含めたアレルギー学的諸検 查を施行し，そのアレルゲンがスギ (Japancse Cedar, Cryptomeria japonica) の花粉であることを知つた

これたより従来稀であるとされていた花昐症が本邦 にも存在することを知り，本症に対してはスギ花㤋应 (Japanese Cedar Pollinosis) と命名しすでに報告し心 ところであるが15)16)，その際あらためて花纷店の研究に は空中飛散花粉の検索が根本的に重要であることを知つ た.

本邦においても空中飛散花扮に関する研究は若千なさ

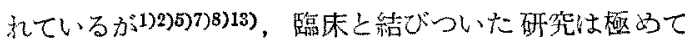
少い，そこで今回著者らは，栃木日光地方のみならず， 東京都目黒区に沶いても空中飛散花扮の検索を行つてみ た。調查期間は, 東京都目黒区に抋いては 1964 年の 1 年 間，栃木県日光地方に和いては 1963 年と 1964 年の 3 月 から 5 月までの 3 力月間である. 更に時間的变動即ち日 变動炕ついて，また飛散条件と最も関連があると考学ら れる湿度との関係沉ついて, 通風乾湿計を用いて湿度を 測定し検索した．最後にこ礼ら空中飛散花㤋の検索とそ の臨床的意義について若干の検討を加克報告与る。

\section{空中飛散花粉検索法}

空中飛散花粉の採集方法注，日贸動，季節变動の観察 に便利なスライドグラス法 (Slide method) で行つた. 先づ䟝上約 $1.5 \mathrm{~m}$ のところに花粉棌集台 (Slide exposure stand) を設置し，その中に白色ワセリンを染布し たスライドグラスを，午前9時か翌日の午前9時までの

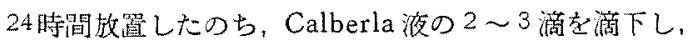
$24 \mathrm{~mm} \times 32 \mathrm{~mm}$ のカバーグラス起が鏡娭した．Calberla 液の組成壮19)、はグリ七リン $5 \mathrm{cc}, 95 \% 0$ アルコール $10 \mathrm{cc}$ ，蒸留水 $15 \mathrm{cc}, 2$ 润つ飽和フクシン溶花上り成り， 花扮はフタシンにより赤色に染まる。

\section{空中飛散花粉の季節的変動}

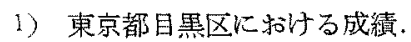

第1 図注 1964 年東京都目黑区に括行る1年間の空中 飛散花粉総数の变動を示している。

この上5に花粉数の增减を示与曲線を花粉数曲楾 (Pollen curve) といい，一般江飛散数は24時間に $1 \mathrm{~cm}^{2}$ に落下する花汾数をむつて表す

この花粉数曲線によれば，東京においてはすでに1月 末には空中に花扮が飛散しており，大体10月まで花㸮 の飛散がつがく．しかし11月上12月には殆ど花粉はみ られない、1月末から10月まではかなりの数の花㸮が

第 1 图空中飛散花粉總数の変動（東京都目黑区－1964 年）

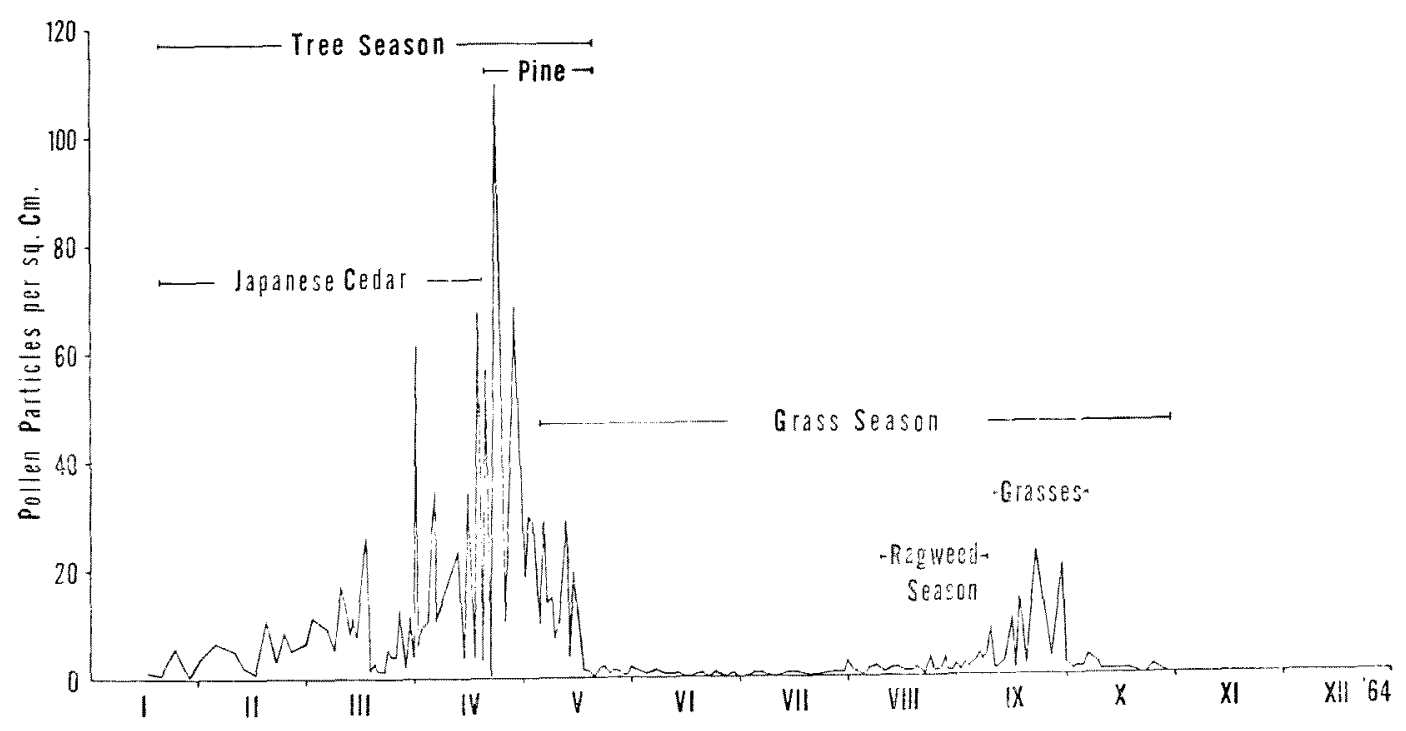


ピークを示す 飛散数の点から主なるのを次に記す

Tree season（木本植物の開花期）は1月末一 5 月中 旬にみられる。その主体をな正花枌は，3月中旬をピー クとして1月末から3月下旬に現秃るスギ (Cryptomeria japonica) がある. 多い日はその飛散数は $1 \mathrm{~cm}^{2}$ 内 に25個みられた（1964年3月17日）。次に4月上旬を ピークとするヒノキ (Chamaecyparis obtusa) がみら れる。飛散数の多い日は $1 \mathrm{~cm}^{2}$ 内に 60 個（1964 年 4 月 1 日)，65㮯（1964年4月18日）などみられた。次は 4 月下旬之5 月上旬をピークとするマッ属（クロマッ Pinus Thunbergii 及びアカマッ Pinus densiflora)が みられる、飛散数の多い日は $1 \mathrm{~cm}^{2}$ 内に 93 個 (1964年 4月23日)，24個（1964年5月2日）などみられた。 クロマツとアカマツは開花時期に差があると言われ，従 つて前のピークはクロマッ. 後のピークはアカマッによ るるのと考えられる.上記の主要花粉の他にわつかなが ら，力バノキ科 (Betulaceae)。一科 (Ulmaceae) の 花粉が 4 月と 5 月にみられた。

Grass season（草本植物の䦥花期）は 5 月〜 10 月ま でみられるが，5月〜8月のイネ科 (Gramineae)の花 粉は極少からた。9月〜10月のイネ科はメヒシバ (Digitaria adscendens) を主体としてピークをつくつ ている、9月にはカナムグラ(く放 Humulus japonicus）の花粉がメヒシバと混じて多少みられた。

Ragweed season（所謂ブタクサ season）は一般に 8月〜9月に現われる。

東京都目黑区に拈いては，8月12日〜9月7日の間 に出現をみているが，その飛散数は極めて少く，クワモ ドキ (Ambrosia trifida) も附近に生育しているので多 少含まれるかと思和れるが，それらの花粉は区別でき ず,ブタクサ属 (Ambrasia) と思われるものはブタク サとしたが，それでも $1 \mathrm{~cm}^{2}$ 内に2〜3個をみるのみで あった。

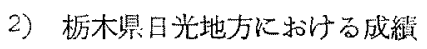

前述の如く1963年著者らがスギ花粉症（Japanese Cedar Pollinosis) を発見したのがこの日光地方であ る. 1963 年と 1964 年の3月より5月までの 3 力月間即 ち Tree season に扣いて空中飛散花粉を検索した結 果, 第 2 第 4 図の如き花数数曲線を得た。1963年の 成績は第 2 因に示されるが，測定回数が少く，いささか 不充分であるが，1964 年の成續は第 $3 ， 4$ 図に示され， ほぼ隔日の測定で满足すべき花粉数曲線と考えら机る。
第2图 スギ・アカマッカパキ属の変動 (日光地方・1963年)

Dercm²

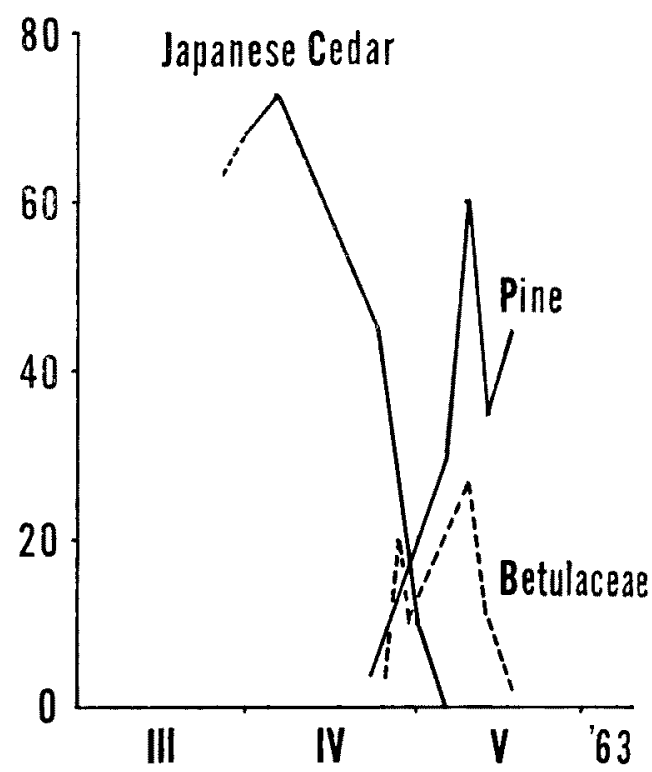

第 3 図 空中飛散花粉総数の变動（日光地方・1964年）

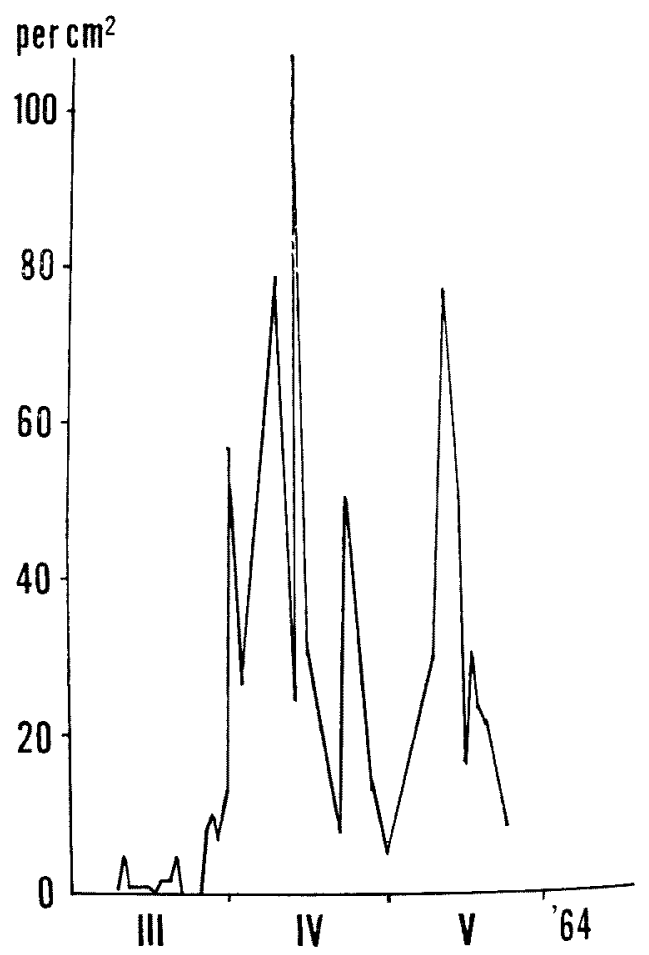




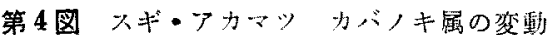
（日光地方・1964年)

\section{per $\mathrm{cm}^{2}$}

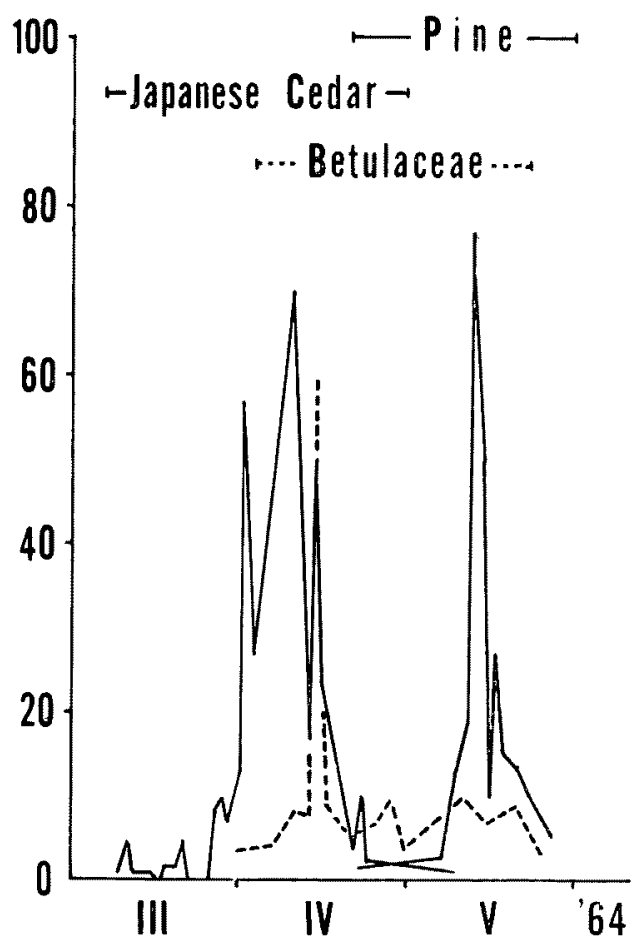

1964年の花粉数曲楾（第3図）を双ると日光地力にお。 いては3月上旬から花粉の飛散を認め，4月に入ると共 に急激に增加して4月中旬には $1 \mathrm{~cm}^{2}$ 内に 110 個の花枌 を認めた。 4 月下旬にも1つのピークがあり，5月始め は一時花粉は少く，5月中旬になつて又ピークがある。

この時には $1 \mathrm{~cm}^{2}$ に約 80 個の花粉を認めた，去して 5 月下旬に至り急激に減少している。この飛散総数の增減 を支配する主な花粉についてそれそれ花粉数曲線をつく つたのが第 4 図である。

Tree season の先づ最初以及ら孙花粉はスギ (Cryptomeria japonica) であつて，3月上旬に現われ，4 月上旬にピークをつくり，4月下旬まで飛散がつづく。 飛散数の多い日は $1 \mathrm{~cm}^{2}$ 内に 70 個(1964年4月10日) 又 られた．次にみられるのはカバノキ属 (Betulaceae) で，4月上旬に現われ，4月中旬にピークをつくり，5 月まで飛散がつづく，飛散数の多い月は $1 \mathrm{~cm}^{2}$ 内に 59 個（1964年4月14日）又られた，最後に多量の飛散を示 すのがアカマッ (Pinus densiflora) であつて, 4 月下
旬に現かれ，5月中旬にピータをつくり，5月末にも海 吕程度の飛散を及てい省、飛散数の多い:日は $1 \mathrm{~cm}^{2}$ 内以 77 個 (1964年5月12日) 欢られた，以上の主要花粉以外 に多少の飛散をみるのは，4月上中旬のナナギ属（Saliceae), 4 月下旬加5 5 月上旬加计てのヒノキ(Chamaecyparis obtusa)，5月下旬のカラマッ (Larix) で あつた。

\section{空中飛散花粉の日変動と湿度との関係}

飛散数の年閏のピークの内，スギについて飛散する时 期が1日の内でも时間的に定まつているかどらかを， 1964 年3月31日の0特から4月2日の24時まで 3 日 間計 72 時間それぞれ】時間ごとにスライドグラスを取 り换え，同侍にアスマン通風乾湿計にて湿度を测定し， これらの関保をそれぞれ検索した．測定地は栃木紧日光 地方である。第 5 图第 6 図に和ける○，(1)，○の記号は それぞれ快腈，腈，绶を表わし，同時に日出，日没の時 閒，天候を表示した。第5図は3月 31 日の成續で，こ

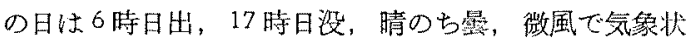
態としてはほぼ標準状態と考えられる。そこで1日の我 散数を $100 \%$ として我散時間との関係を調べたとこる， 全体を通じてい光ることは，湿度が低下するに彷つて升 散数が增加し，時間的には 1 日のうちで9時から17時 までに飛散している。第6因は4月1日と4月2日の成 績である。気象状態は4月1日は6時日出，17時日没， 睛のち量，夕方から風が出て夜半には突風となり，4月 2 日0 時から 2 特頃に寒冷前線の道過马欢ている。 4 月 2 日は6 時日出，17時日没，快睛のち睛であつた。この 両日を通じて特徴的な点は藇冷前線の通過と共に異常な 湿度の低下と突風をみていることである，この際の飛散 数がどう恋るかが與味深いものである。

さて湿度は第5 図に双るごとく通常日没と共纪上昇す

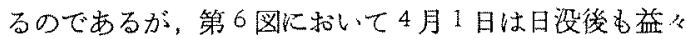
湿度は低下し，同時に風も出て，飛散数は減少するどこ ろか雨び增加している，寒冷前線の通過と共に飛散数は 異常に增加し，4月2日の全体の飛散数の約1/3がこの 2 時から3 時までの1時間に飛散している，乙の後6時 の日出と共に一時湿度恃上昇し，この時に飛散数は減少 した。そその後日中再び湿度は低下せるもこの際には飛散

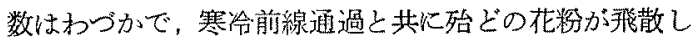
てしまつたものと考えられる。さていずれにして子1日 のうちで湿度が $80 \%$ 以下になる牙散し始め，ピーク はその時の気象状態によつて差があるが，その日がその 


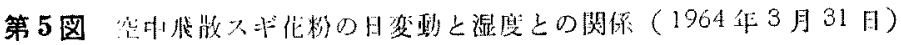

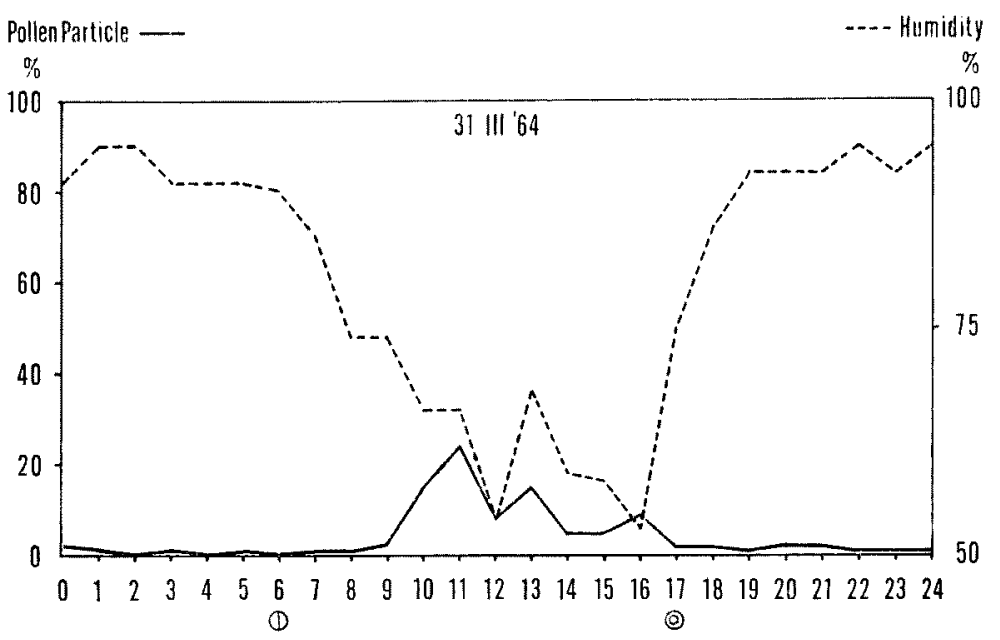

第 6 図空中飛散スギ花粉の日変動と湿度との関係（1964年4月1日〜2 日）

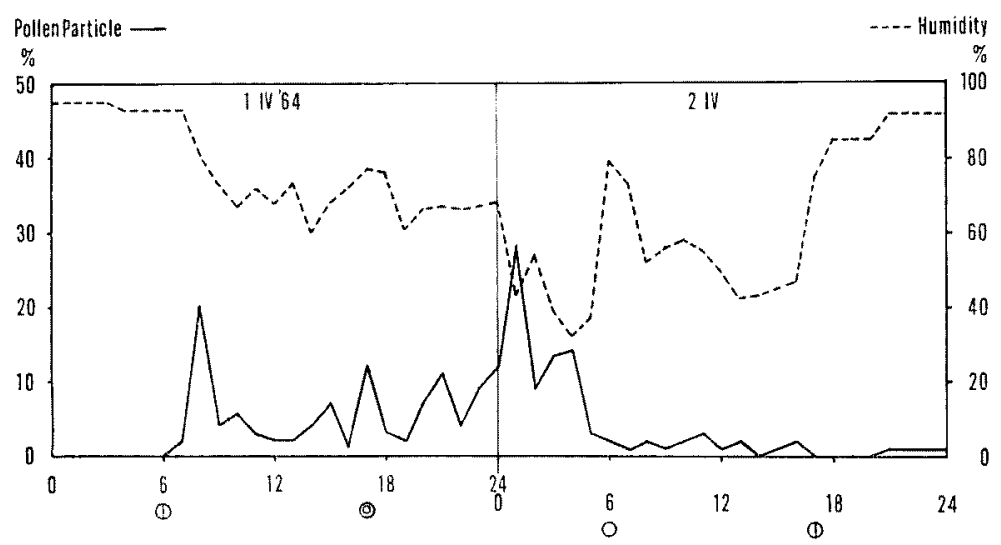

Кおいては Tree season に枋 ける主要花粉であるスギ、マッ 属は，それが大量に飛散するに るかかわらす：感作された個体 の少いことからこれらの花㸮は 極めて抗原性が低いと考点られ ている. 事奏東京地方に拊るる アレルギー性鼻炎患者につい て，皮内反応炕り感作状洗を 検索するに第 1 表の如く， ス ギ，マッ属の花粉に感作せられ た患者は比較的少いことが判 る、しかしながらこのよらに抗 原性の低い之考觉られるスギ花 粉でさ文も，枋木県日光地方に 㕲ける如く，持続的に大量の张 散を示すときは花粉症の発生を みるのである. 同様に大量の飛 散数を示すマッ属についてもと の花粉症は存在しないとは決し て䀿言できないと思う。

米国に和惊る花粉正の最大の 原因であるブタクサ属は，本邦 においても最も抗原性の強い花 粉の一つである. 特にクワモド キ (Giant ragweed)はブタタ サ (Short ragweed) よりも抗 原性が強いといわれている。第 1 表に示す如くアレルギー性鼻

まますまり湿度が高くならない限り飛散数は夕方まで続 くが，急に湿度が上昇して $80 \%$ 以上になると飛散数㤌 念激に減少するのがみられた。

ここでスギ花汾の場合は，我散数と飛散時は湿度に一 潘深い関係を示すよらに思加れた。

な叔異常な湿度の低下と強風をともなら寒冷前線通過 の際には，極めて多量の花粉が短時間に飛散することか゚ わからた。

\section{花粉症成立条件としての花粉の抗原性と飛散量}

緒言でる述べた加く，花粉症の発生には原因となる花 粉が空中に存在することが第 1 条件であるが，ただ花粉 が存在しても必ずしも花粉症が発生するとは限らず，花 粉の抗原性と量とが問題になる.米国に抽いては一般に Tree season の花粉症は軽症であるとされている。本邦
炎患者の $37 \%$ \%ブタクサ陽性である.しかしこのよう に強力な抗原性を有するブタクサは比較的全国的に生育 がみられるよ5であるが，関東地方に执いては繁茂地は 比較的限られているよらである，著者らの調查した東京 都目黑区にる生育はしているが，少くとも花粉症の発生 にはほと遠い张散量である，又幸いなことにクワモドキ の生育は末だ少いようである。

ブタクサに次いで皮内反応陽性率の高いのがカナムグ ラであるが，飛散数はわつかと考㝋られるのに感作され た個体は多く，従つて抗原性は相当に強いむのと思方 れ，その花粉症も案外存在するのかも知れない，ただ タタサと開花期が一部重復する点との花枌症を見出すこ とはもづかしいかと思われる。

な拈 Grass の花粉の抗原性は Ragweed の花粉と 
第1表 アレルギー性舆炎 46 例に特ける吸入 性アフルゲン皮内反沦陽性等

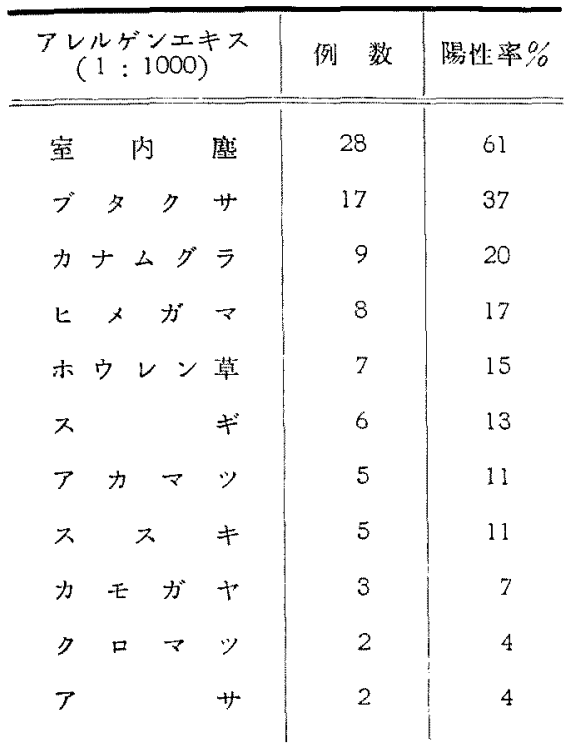

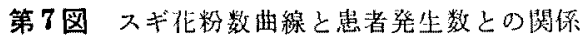

\section{percm $^{2}$}

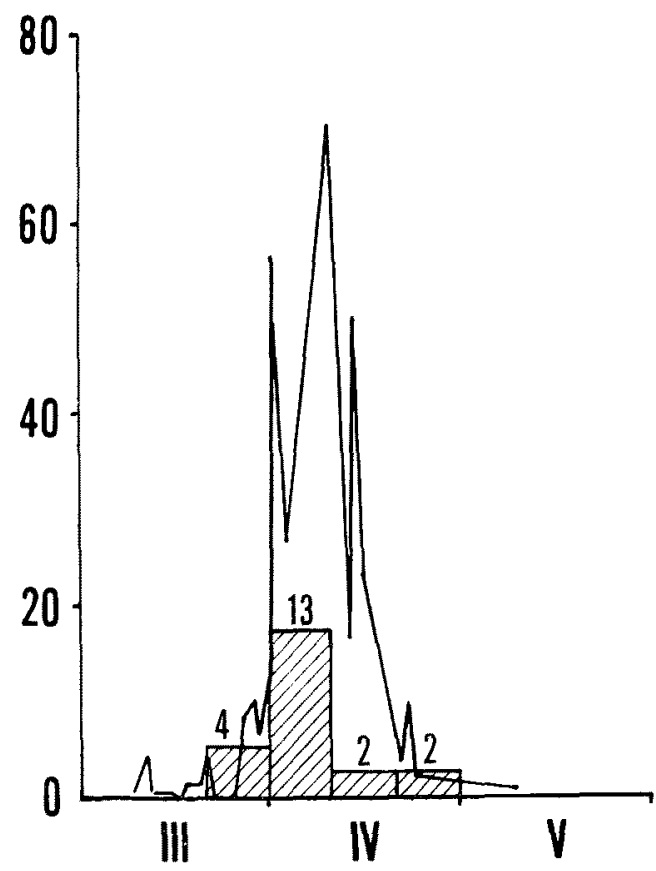

Tree の花粉の中間に位置するものと考光られ，本邦に 执いても近年牧草繁茂地で Grass の化粉による花粉柱 が見出さ机て来ている。

次に花枌淀成立のために飛散花粉量が問題となるが， 一般に $1 \mathrm{~cm}^{2}$ あたり 24 時間落下する花粉数が 40〜50 個で花粉症を起すと訔われ，20個以下では正状は起り 難いとされている。

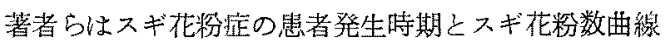
とを此較検討することによつて，第 7 四にみるこ゚とく， 少くともスギ化粉症に関しては，一般に $1 \mathrm{~cm}^{2}$ あたり24 時間に落下する花粉数が 10 個以下ではたと克感作され た個体にあつてあ症状は発現し難いものと考点ている。

又花粉症の成立には，持続的にしか子永年にわたる多 量の花粉との接触染必要で，この点日本各地に括いて も，少くとも日光地方之同様持綂的に $1 \mathrm{~cm}^{2}$ あたり 24

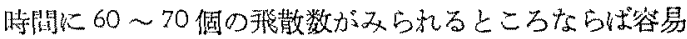
にスギ花粉正は成立するものと考えている。

\section{総括之考按}

本邦に括いて空中我散花粉の季節的变動克観察した文 献としては次の如きもが正られる。 Hara $(1935,1939)$ 122）は札璂，東京及び神戸における観察成績を示してい るが，スギ及びブタクサ花粉の惩散については言及しな からた

茫木 $\left.(1960)^{5}\right)$ 性東京都文京区と千葉県習志野市に和 ける観察で，スギ，マッ属及びブタクサの花㸮が季節的

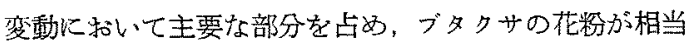
数秋散していることを指摘し，その後の報告 6 )でブタク

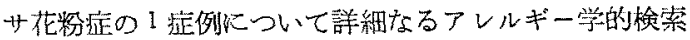
を行つている。幾瀨ら (1962)8) b千葉県習志野市及び 東京都の一部に括いて観察し，特に湿度並びに高度と我 散数との関係につき言及している。

1964 年著者らは特に臨休的見地より空中飛散花粉の 研究を行い，東京に和け当空中飛散花粉の季節的贸動 は，荒木の報告と同じく three season 即ち Tree season, Grass season 及び Ragweed season を示すいわ ゆる米国型であり，ての主要花粉はスギ，ヒノキ，マッ 属，ブタクサ，イネ科の植物の花粉であることを知つ た。しかしブタクサに関しては，荒木，幾瀬らの成績と 比较して，東京都目黑区に沏いては東京都文京区や于葉 目署志野市にみら狆る如き多量の飛散数心認められなか つた、ブタクサは接で本邦に㕕く生育をみているとい われるにもかか和らず，特定の地域に群落をつくつてい 
るよらで，たとえ若干の生䏍をみるも一般にはとの飛散 数は未だ比較的少量であることを知つた。しかしながら 臨床的以花粉抽出液比上るアレルギー性與炎の皮内反応

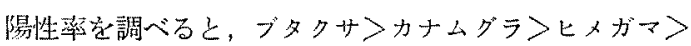
ホウレン草〉スギ>アカマッの順であり，換言すればこ れは又抗原性の順とも考兵られる。花粉婝の成立には花 粉の抗原性と飛散数とが基本的には重要な役割を演ずる のであつて，この点ブタクサ花枌症は比較的少量の飛散 数でも成立するであううし，スギ花粉泟は大量の飛散数 がなけ机ば成立しないと考之られる。そして少くともス ギ花枌症は著者らの日光地方に怙ける観察では， $1 \mathrm{~cm}^{2}$ 西たり 24 時間の飛散数が 60〜70 個に及び，乙か子車持繶 的に永年に加たつて接蚛せ权ば成立しないことがかから た、なおスギ花粉症の発生状況とスギ花枌数曲線とを比 較椮討した結果，少くとも不化粉か： $1 \mathrm{~cm}^{2}$ あたり 24 時間以 10 個以下の場合以は患者は症状を現わさないか， 現わして㮀めて軽微であることも知つた。

しかし各患者についてその発作発現と花粉量との関係を 調べるとするならば、無抗原室に括ける観察が必要と思 ら.

次化飛散量を支配する要素の一つとして気象状態があ る。特に湿度，風速，気争变化等が飛散数を变光る。空 中飛散花粉の日変動と湿度との関係については幾瀨らの 詳細な観察があり，クロマッの花粉の飛散数上飛散量は 湿度に最も関係し，ブタクサの花㸮については開䒺時の 湿度が関係すると述べている。著者らはス弌花粉症との 関係から，疠木県日光地方において主として空中飛散ス ギ花粉の日変動と湿度との関係を観察した．1時間每に 72 时間にわたる 観察から， スギの花粉についてその我 散数と飛散時は湿度に最も樑、関俰を示すようであり， 更に與味あることには，異常な湿度の低下と強風を伴う 寒冷前線の通過の際注極めて多量の花粉が短時間内比 飛散することを知つた。このことからいわゆる気像病と アレルギーとの関倸の一端をうかがい知ることができる ものと考完る.

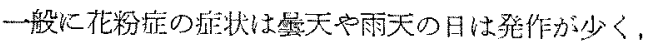

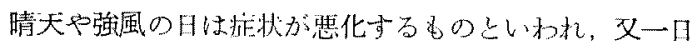
の内でも朝から午前中溌作が頻発するともいわ机てい る、これも著者らの観察の如く日の出々とも《湿度が低 下し，逆滛散数の方は增加し，大半の花粉が午前中に 飛散することからも理解できる，更に睛天の日は湿度も 低く，しかも强風の日は多量の花粉が挀散与るため怔状 が悪化するのである。
さてひるがえつてわが国に扣いて従来花㸮定が稀であ ると考克られていた理由について若干考察してみたい， その理由の第 1 は原因となる花粉をもつ植物の生育が少 いのであろらといらこと，あるいはたとえ存在していて もわが国は常に季節風に洗われていて放出された花粉も 次第に薄和てアメリカ大陸の大気中とは比較にならぬ汪 ど少量の花粉が存在しているに過ぎないのではないかと いらことである．第2には湿度が高いといらことであ り，これらの理由からかが国の大気中には花粉の数が少 くそのために花枌症の原因とはならないとの推論がなさ れていたものと考穴られる。 これに加えて花粉症に関す る基礎的研究も少く，従つて臨床的にも花粉症の適確な る診断方法の確立がなされていなかつたためとも考え られる。極言すれば花粉症に刘与る認識の不足にあつた ためともい光るのであって，わが国では花粉症にかから ても知らないでいるかまたは他の疾患だと考党ていた

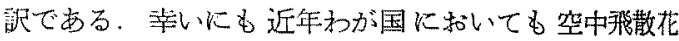
粉の検索が行われ，花粉症の原因となり得る各種植物の 生育も知られるようになり，これに加えて臨床面でる花 粉症の診断方法が進歩し，現在ブタクサ花粉症，スギ花 粉症，その他若干の Grass に上る花粉症の発見がなさ れるに至つている，しかしながら空中飛散花㸮の調查む 未だ局在的であり，今後は日本全土にわたつて調查が必 要である。すでにアメリカに呿いては花粉症の対策から 大陸内の数十力所以花粉の钼測所が設けられ，天気図に 承相当するよらな花粉の量を図示した花粉地図の作製か なされて来ている，これには植物学者の協力も必要であ り，著者らは早急にこの種の研究が進められることを希 望するものである。

\section{結語}

1）著者らは1964 年に東京都目黑区に执いて，空中 我散花特の季節的变醘を観察した， その結果 Tree season, Grass season, Ragweed season の3 期がみられ, スギ、ヒノキ，マッ属，ブタクサ、イネ科植物の花粉が 主要な部分を占めることを知つた。ブタクサに関してそ の生育はみられるが未だ飛散数は極めて少いことも知的 た.

2) 1963 年と 1964 年に杤木目日光地方に打いて 3 月 より 5 月までの 3 力月間空中飛散花粉の検索を行つた. 日光地方に和いてはこの期間は Tree season で, 主要 花粉はスギ，カパノキ属，アカマッであることを知 た. 
3）空中飛散スギ花粉の日変動と湿度との関係を钼察 し，その飛散数は湿度に最も樑い関係を示寸ものと思わ れた. 寒冷前線通過の際には栖めて多量の花粉が短時間 に飛散することを知つた。瀶床应状が気像状態にも左在 されていることが，飛散数と湿度の閔㐿から理解でき た。

4)臨休的観祭加ら各種花粉の抗原性について言及 し，花粉症成立条件としての飛散量をスギ花粉症に和い て検討した．スギ花枌拝の成立条件しして，飛散量は $1 \mathrm{~cm}^{2}$ あたり 24 時間 の飛散数が $60 \sim 70$ 個に及ぶこ上 が必要で，しかも持続的に永年にわたり昹露されていな い限りスギ花粉症は成立しないるのと考无る，更に患者 の発作は，飛散数が $1 \mathrm{~cm}^{2}$ あたり 24 時間に 10 個以下 の時期にはほとんど発現しないことを知つた。

5）従来わが国に花粉症が稀であると考えられていた 理由について考察し，花粉症研究に和壮る空中訨散花粉 検甞の重要性を強調した。

\section{文献}

1) Hara, H. J.: Hay fever among Japanese; II, Arch. Otolaryng. 21, 9, 1935.

2) Hara, H. J.: Hay fever among Japanese; III, Arch. Otolaryng. $30,525,1939$.

3) 青木己三男：諸種の花粉に因る 奏験的過敏性現象の研究，成医会誌，60，1124，1941。 4) 天埜景康：枯草知に関する病原植物之簡易特異性診 断法，日耳净，42，453，1936。5) 荒术英齊: 花粉 症の研究； I，アレルギー19, (8), 648, 1960.

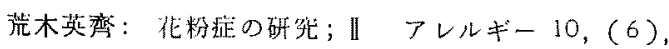

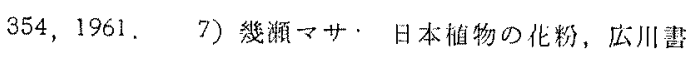

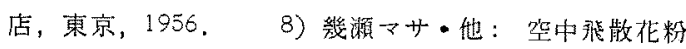
以ついて，植物砄究誋，37，2，33，1962。9）池由 正男：花粉「アレルギー」の研觉，裂応医学，18，10， 1153，1938. 10) 石撚達：化粦アレルギー、ア レルギー，金原出版，柬京，218，1958，11）岩败 洋造：北粉，其立出敞，1956。12) 北原静夫： ア

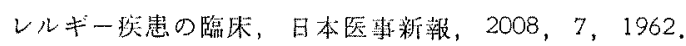
13）杉田和琴・他：花粼症の研究；I，アレルギー。 $13(1,2) 19,1964.14)$ 橋本泰淁・他：アレル ギー性舅炎に扣けるブタクサ化粉 Ragweed pollen の

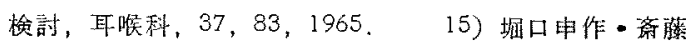

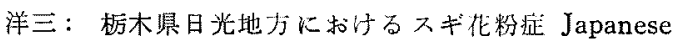
Cedar Pollinosis の登見，フレルギー。1 $13(1,2)$,

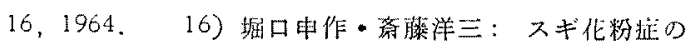
臨床的穊察，日耳鬾， $67,3,532,1964$.

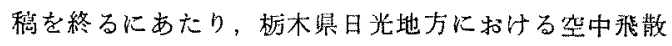

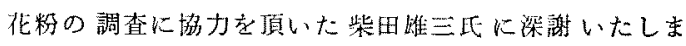
于

本諭文の要旨は，1965年3月第47回日耳率関東地方

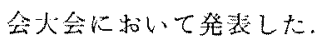

(原稿到着=吸和 40.4 .9 日) 